\title{
PEMECAHAN MASALAH RUTE KENDARAAN DENGAN TRIP MAJEMUK, JENDELA WAKTU DAN PENGANTARAN-PENJEMPUTAN SIMULTAN MENGGUNAKAN ALGORITMA GENETIKA
}

\author{
Suprayogi*, Muhammad Syafaruddin Mahaputra \\ Fakultas Teknologi Industri, Institut Teknologi Bandung \\ (Received: Octobre 18, 2016/ Accepted: July 17, 2017)
}

\begin{abstract}
Abstrak
Masalah rute kendaraan (MRK) merupakan salah satu masalah keputusan yang memegang peranan penting dalam kegiatan transportasi dan distribusi dalam manajemen logistik. MRK terkait dengan penentuan rute-rute kendaraan yang meminimumkan total jarak yang ditempuh dengan memperhatikan pembatas-pembatas berikut: (1) tiap rute berawal dan berakhir di depot, (2) tiap kendaraan hanya melayani satu rute, (3) tiap pelanggan dilayani oleh satu rute, (4) seluruh pelanggan harus dilayani, dan (5) total muatan untuk tiap rute tidak melebihi kapasitas kendaraan. Dalam literatur, definisi ini merupakan definisi untuk MRK dasar atau klasik. Makalah ini membahas perluasan dari MRK dasar yang mencakup karakteristik-karakteristik berikut: (1) trip majemuk (TM), (2) jendela waktu (JW) dan (3) pengantaran-penjemputan simultan (AJS). Metode pemecahan berbasis algoritma genetika $(A G)$ diusulkan untuk memecahkan MRK yang dibahas dalam makalah ini. AG yang diusulkan diuji-coba dengan menggunakan beberapa contoh hipotetik.
\end{abstract}

Kata kunci: masalah rute kendaraan; rute majemuk; jendela waktu; pengantaran-pengambilan simultan; algoritma genetika.

\begin{abstract}
Vehicle routing problem (VRP) is one of decision problems having an important role in transportation and distribution activity in the logistic management. The VRP deals with determining vehicle routes that minimizes total distance by satisfying the following constraints: (1) each route starts and ends at the depot, (2) each vehicle serves only one route, (3) each costumer is served by one route, (4) all customers must be served, and (5) total load for each route does not exceed the vehicle capacity. In literature, this definition is the definition for the basic or classical VRP. This paper discusses an extension of the basic VRP including the following characteristics: (1)multiple trips (MT), (2) time windows $(T W)$, and (3) simultaneous pickup-delivery (SPD). A solution method based on genetic algorithm (GA) is proposed to solve the VRP discussed in this papaer. The proposed GA is examined using some hypothetical instances.
\end{abstract}

Keywords: evhicle routing problem; multiple trips, time windows; simultaneous pickup-delivery; genetic algorithm

\section{Pendahuluan}

Masalah rute kendaraan (MRK), yang pertama kali diperkenalkan oleh Dantzig dan Ramser (1959), merupakan salah satu permasalahan yang memegang peranan penting dalam kegiatan transportasi dan distribusi dalam manajemen logistik. MRK terkait dengan penentuan rute-rute kendaraan yang meminimumkan total jarak dengan memperhatikan pembatas-pembatas berikut: (1) tiap rute berawal dan berakhir di depot, (2) tiap kendaraan hanya melayani satu rute, (3) tiap pelanggan dilayani oleh satu rute,

\footnotetext{
${ }^{*}$ Penulis Korespondensi.

email: yogi@mail.ti.itb.ac.id
}

(4) seluruh pelanggan harus dilayani, dan (5) total muatan untuk tiap rute tidak melebihi kapasitas kendaraan. Dalam literatur, definisi ini merupakan definisi untuk MRK dasar atau klasik. Makalah ini membahas tentang perluasan dari MRK dasar yang mencakup karakteristik-karakteristik berikut: (1) trip majemuk (TM), (2) jendela waktu (JW) dan (3) pengantaran-penjemputan simultan (AJS). Selanjutnya, MRK yang dibahas dalam makalah ini disingkat dengan MRK-TM-JW-AJS.

TM merupakan salah karakteristik dalam MRK yang sering muncul dalam situasi praktis. Dalam MRK dasar, tiap kendaraan diasumsikan hanya melayani satu rute sepanjang horison perencanaan. MRK-TM merupakan MRK yang mengijinkan suatu 
kendaraan untuk melayani satu rute atau lebih sepanjang horison perencanaan. Salah satu pembahasan awal dari MRK-TM antara lain dilakukan oleh Taillard dkk. (1996). Dalam literatur, MRK-TM dikenal juga dengan istilah MRK dengan pengunaan kendaraan majemuk. Dalam konteks MRK-TM, terdapat dua istilah umum yang digunakan seperti didefinisikan oleh Brandão dan Mercer (1997), yaitu trip (rute) dan tur. Suatu trip atau rute merupakan suatu urut-urutan kunjungan kendaraan yang berawal dan berakhir di depot. Suatu tur merupakan kumpulan satu atau lebih trip atau rute yang dilayani oleh satu kendaraan yang sama.

Dalam MRK dasar, tiap pelanggan diasumsikan dapat dikunjungi kapan pun sepanjang horizon perencanaan. Dalam MRK-JW, tiap pelanggan hanya dapat dilayani oleh suatu kendaraan pada suatu interval waktu tertentu dalam horizon perencanaan. Interval waktu ini disebut dengan jendela waktu. Suatu jendela waktu dicirikan oleh saat buka dan saat tutup. Pelayanan pada tiap pelanggan hanya dapat dimulai tepat pada atau setelah saat buka. Jika kendaraan tiba pada suatu pelanggan sebelum saat bukanya, maka kendaraan tersebut harus menunggu. Pelayanaan pada tiap pelanggan harus diakhiri sebelum atau tepat pada saat tutup. MRK-JW telah banyak dibahas dalam literatur. Beberapa diantaranya adalah Solomon (1987). Dalam konteks adanya JW, MRK tidak hanya terkait aspek spasial (penentuan rute), namun juga terkait dengan aspek temporal (penentual jadwal) seperti dikemukakan oleh Bodin dan Golden (1981).

MRK dasar hanya berkaitan dengan operasi pengantaran atau penjemputan saja, tidak keduanya. Di sini, permintaan pada tiap pelanggan hanya terkait dengan permintaan pengantaran (untuk kasus operasi pengantaran) atau permintaan penjemputan (untuk kasus penjemputan). Dalam situasi nyata, adakalanya tiap pelanggan memiliki permintaan pengantaran dan penjemputan sekaligus. MRK dengan karakteristik ini disebut dengan MRK-AJS yang pertama kali diperkenalkan oleh Min (1989).

Kombinasi karakteristik-karakteristik TM, JW dan AJS dalam MRK telah dibahas dalam literatur. Kombinasi antara TM dan JW telah dibahas antara lain oleh: Brandão dan Mercer (1997), Suprayogi (2003), Suprayogi dan Imawati (2005), Suprayogi dkk. (2005, 2007, 2011), Battarra dkk. (2009), Azi (2010) dan Hernandez dkk. (2014, 2016). Ong dan Suprayogi (2011) membahas MRK-TM-JW dalam konteks backhauls. Nguyen dkk. (2013) membahas MRK-TM-JW dalam kaitan pembatas sinkronisasi waktu. Cattaruzza dkk. (2014) membahas MRK-TMJW dengan melibatkan atribut release date. MRK dengan kombinasi karakteristik-karakteristik JW dan AJS (MRK-JW-AJS) telah dibahas oleh Mingyong dan Erbao (2010), Fan (2011), Wang dan Chen (2012, 2013), Liu dkk. (2013), Avci dan Topaloglu (2015) dan Wang dkk. (2015).
Sepanjang pengetahuan, MRK-TM-JW-AJS sangat sedikit dibahas dalam literatur. Suprayogi dan Priyandari (2007, 2009) merupakan literatur yang membahas MRK-TM-JW-AJS. Suprayogi dan Priyandari (2007) mengusulkan metode pemecahan yang berbasis algoritma penyisipan sekuensial yang merupakan metode heuristik konstruksi. Suprayogi dan Priyandari (2009) mengusulkan metode heuristik perbaikan dalam bentuk metode pencarian lokal (local search) dengan menggunakan solusi awal yang dibangkitkan menggunakan metode penyisipan sekuensial dari Suprayogi dan Priyandari (2007). Struktur ketetanggaan dibentuk dengan menerapkan operasi-operasi perbaikan yang terdiri atas operatoroperator relokasi, pertukaran dan persilangan. Ketiga operator ini dimodifikasi dari Suprayogi dkk. (2007) yang sebelumnya diterapkan untuk MRK dengan trip majemuk dan jendela waktu.

MRK dasar dan perluasannya merupakan salah masalah optimisasi kombinatorial yang sulit seperti dikemukan oleh Lenstra dan Rinnooy-Kan (1981). Oleh karena itu, pemecahan MRK dan varianvariannya banyak menggunakan metode-metode heuristik.

Makalah ini mengusulkan metode algoritma genetika (AG). AG merupakan salah satu metode metaheuristik yang mengambil analogi dari konsep evolusi. AG banyak digunakan untuk memecahkan masalah-masalah optimisasi kombinatorial yang sulit, termasuk MRK. Kontribusi dari makalah ini memberikan metode alternatif untuk pemecahan MRK-TM-JW-AJS.

\section{Definisi Masalah}

Definisi dari MRK dengan trip majemuk, jendela waktu dan pengantaran dan penjemputan simultan dalam makalah ini diambil dari Suprayogi dan Priyandari (2007, 2009). Misal terdapat satu depot dan sejumlah $\boldsymbol{n}$ pelanggan. Untuk simplifikasi, misal depot disimbolkan dengan angka 0 dan pelanggan-pelanggan dinyatakan dengan angka bulat 1 sampai dengan $\boldsymbol{n}$. Misal $\boldsymbol{C}=\{\boldsymbol{0}, \boldsymbol{1}, . ., \boldsymbol{n}\}$ menyatakan himpunan pelanggan. Misal himpunan $N$ menyatakan gabungan depot dan himpunan pelanggan, yaitu $\boldsymbol{N}=\boldsymbol{C} \cup\{\boldsymbol{0}\}$. Tiap pelanggan $\boldsymbol{i} \in \boldsymbol{C}$ berasosiasi dengan kuantitas permintaan penjemputan $\boldsymbol{p}_{\boldsymbol{i}}$, kuantitas permintaan pengantaran $\mathrm{d}_{\mathrm{i}}$ dan jendela waktu $\left(\boldsymbol{e}_{\boldsymbol{i}}, \boldsymbol{l}_{\boldsymbol{i}}\right)$ dengan $\boldsymbol{e}_{\boldsymbol{i}}$ dan $\boldsymbol{l}_{\boldsymbol{i}}$ masing-masing menunjukkan saat buka dan saat tutup. Waktu pelayanan pada tiap pelanggan $\boldsymbol{i} \in \boldsymbol{C}$, dinotasikan dengan $\boldsymbol{S} \boldsymbol{i}$, menunjukkan waktu bongkar-muat dan diasumsikan tidak tergantung pada kuantitas yang dibongkar-muat. Asumsi bahwa $\boldsymbol{s}_{\boldsymbol{i}} \leq \boldsymbol{l}_{\boldsymbol{i}}-\boldsymbol{e}_{\boldsymbol{i}}$ untuk tiap $\boldsymbol{i} \in \boldsymbol{C}$. Terdapat sejumlah kendaraan yang berpangkalan di depot dan diasumsikan tak terbatas. Kendaraan-kendaraan 
diasumsikan homogen dengan kapasitas muatan tiap kendaraan dinyatakan dengan $\boldsymbol{Q}$. Asumsi bahwa $\boldsymbol{Q} \geq \boldsymbol{p}_{\boldsymbol{i}}$ dan $\boldsymbol{Q} \geq \boldsymbol{q}_{\boldsymbol{i}}$ untuk tiap $\boldsymbol{i} \in \boldsymbol{C}$. Waktu perjalanan antara $\boldsymbol{i} \in \boldsymbol{N}$ dan $\mathrm{j} \in \boldsymbol{N}$ adalah diketahui dan dinyatakan dengan $\boldsymbol{t}_{i j}$ serta diasumsikan bahwa waktu perjalanan adalah simetris, yaitu $\boldsymbol{t}_{\boldsymbol{i j}}=\boldsymbol{t}_{\boldsymbol{j} \boldsymbol{i}}$. Terdapat jendela waktu pada depot yang dinyatakan dengan $\boldsymbol{e}_{\boldsymbol{0}}, \boldsymbol{l}_{\boldsymbol{0}}$ dengan $\boldsymbol{e}_{\boldsymbol{0}}$ dan $\boldsymbol{l}_{\boldsymbol{0}}$ masing-masing menyatakan saat buka dan saat tutup. Selisih antara $\boldsymbol{l}_{\boldsymbol{0}}$ dan $\boldsymbol{e}_{\boldsymbol{0}}$ pada dasarnya menunjukkan panjang horison perencanaan $\boldsymbol{h}$.

MRK-TM-JW-AJS terkait dengan penentuan rencana tur yang mencakup informasi tentang tur-tur kendaraan dan jadwal. Rencana tur yang diperoleh harus memperhatikan pembatas-pembatas sebagai berikut: (1) suatu tur paling sedikit mencakup satu rute (trip), (2) tiap tur tepat dilayani oleh satu kendaraan, (3) tiap rute (trip) berawal dan berakhir pada depot, (4) total muatan pada suatu rute (trip) kendaraan tidak melebihi kapasitas kendaraan, (5) semua pelanggan harus terlayani, (6) tiap pelanggan tepat dikunjungi satu kali, (5) saat pelayanan bongkar-muat (di depot dan pelanggan) harus dimulai pada atau setelah saat buka, (6) saat pelayanan bongkar-muat (di depot dan pelanggan) harus diakhiri pada atau sebelum saat tutup.

Terdapat tiga ukuran kinerja yang dipertimbangkan yang semuanya diminimumkan, yaitu jumlah kendaraan yang digunakan $\boldsymbol{N} \boldsymbol{V}$, total waktu durasi tur $\boldsymbol{T D T}$, dan rentang waktu durasi tur $\boldsymbol{R D T}$. Waktu durasi tur tiap kendaraan mencakup waktu perjalanan, waktu pelayanan dan waktu menunggu. Waktu durasi tur didefinisikan sebagai selisih antara saat kendaraan mengakhiri pelayanan di depot untuk terakhir kali dengan saat kendaraan mengawali pelayanan di depot untuk pertama kali pada suatu tur. Di sini, saat pelayanan di depot untuk pertama kali pada suatu tur tidak harus terjadi pada saat buka $\boldsymbol{e}_{\boldsymbol{0}}$. Definisi waktu durasi ini diadopsi dari Savelsbergh (1992). Rentang waktu durasi tur adalah selisih antara waktu durasi tur maksimum dan minimum. Meminimumkan rentang waktu durasi tur digunakan dalam usaha untuk menghasilkan waktu durasi tur yang seimbang mungkin untuk seluruh tur.

Pencapaian ukuran kinerja dilakukan dengan urutan prioritas sebagai berikut: jumlah kendaraan, total waktu durasi tur dan rentang waktu durasi tur. Pencapaian ukuran kinerja yang lebih rendah tetap harus mempertahankan pencapaian ukuran kinerja yang lebih tinggi. Misal $v$ menyatakan solusi (rencana tur), penangangan ukuran kinerja majemuk dilakukan dengan metode jumlah terbobot (weighted sum) seperti dinyatakan dalam persamaan berikut:

$F(v)=w_{N T} N T(v)+w_{T D T} T D T(v)+w_{R D T} R D T(v)$ dengan notasi-notasi $\boldsymbol{w}_{N T}, \boldsymbol{w}_{T D T}$, dan $\boldsymbol{w}_{R D T}$ masingmasing menunjukkan bobot yang berasosiasi dengan jumlah kendaraan, total waktu durasi tur dan rentang waktu durasi tur. Pemilihan nilai-nilai bobot dilakukan sedemikian rupa sehingga menjamin pemenuhan urutan prioritas, yaitu

$$
w_{\mathrm{NT}} N T(v)>w_{T D T} T D T(v)>w_{R D T} R D T(v)
$$

\section{Algoritma Genetika \\ Kerangka Algoritma Genetika}

MRK dengan trip majemuk, jendela waktu dan pengantaran-penjemputan simultan yang dibahas dalam makalah ini dipecahkan dengan algoritma genetika (AG). AG dimulai dengan pembangkitan populasi awal sebanyak ukuran populasi yang telah ditetapkan. Tiap individu atau kromosom dalam populasi awal dibangkitkan dengan algoritma penyisipan sekuensial. Nilai fitness dari tiap individu pada suatu populasi dihitung berdasarkan jumlah tertimbang dari ketiga ukuran kinerja seperti telah ditunjukkan dalam persaamaan (1). Berdasarkan populasi saat ini, populasi yang baru dibentuk dengan menerapkan tiga operator genetika secara paralel. Operator-operator genetika yang digunakan adalah elitisme (elitism), persilangan (crossover) dan mutasi (mutation). Jumlah individu yang dibentuk dari ketiga operator ditentukan berdasarkan tingkat proporsi yang ditetapkan. Khusus untuk operator persilangan, jumlah individu yang terbentuk harus merupakan angka genap. Prosedur AG berhenti jika iterasi telah mencapai jumlah generasi maksimum yang telah ditetapkan. Secara umum, langkahlangkah AG yang diterapkan ditunjukkan pada Gambar 1.

\section{Representasi Individu}

Individu direpresentasikan sebagai bilangan bulat. Depot diwakili oleh angka nol dan pelanggan diwakili oleh bilangan bulat positif yang lebih besar daripada nol. Sebuah tur kendaraan dengan dua rute diperlihatkan oleh contoh berikut:

$$
\begin{aligned}
& 0-4-6-2-0-1-10-0 \\
& 0-26-30-1-0-25-53-0
\end{aligned}
$$

\section{Populasi Awal}

Tiap individu dalam populasi awal dibentuk dengan menggunakan algoritma penyisipan sekuensial. Setiap individu dibangkitkan secara acak. Gambar 2 dan Gambar 3 menunjukkan diagram alir dari prosedur pembentukan individu dalam populasi awal dengan menggunakan algoritma penyisipan sekuensial. 


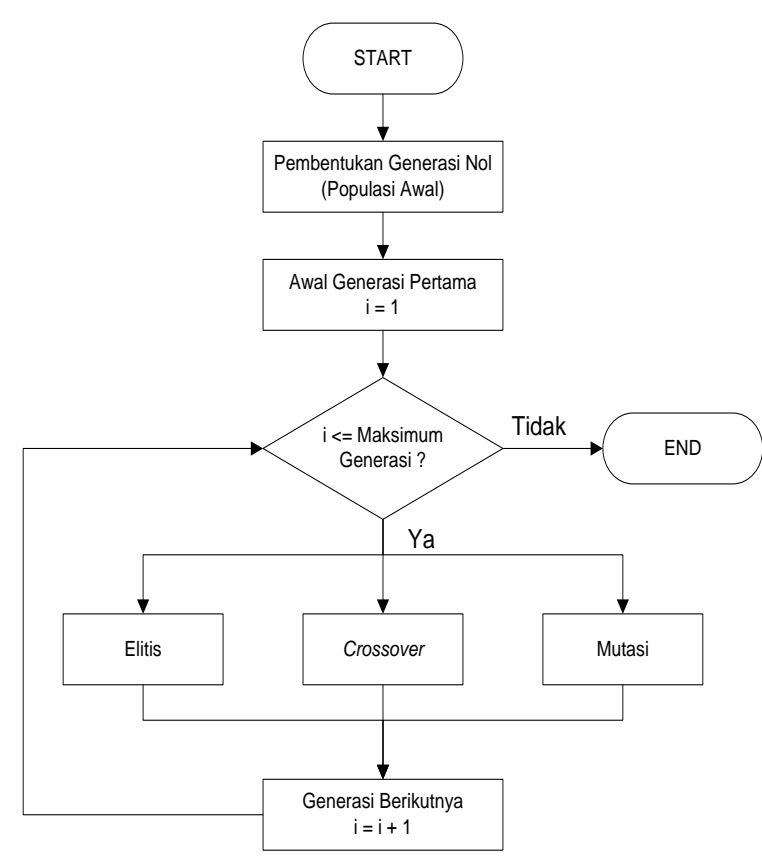

Gambar 1. Diagram alir dari prosedur AG yang dikembangkan

\section{Penentuan nilai fitness}

Untuk tiap individu, nilai fitness dihitung menggunakan persamaan (1). Nilai fitness ini menunjukkan nilai fungsi tujuan.

\section{Operator-operator genetika}

Operator-operator genetika digunakan untuk membentuk populasi baru dari populasi saat ini. Seperti telah dijelaskan sebelumnya, terdapat tiga operator genetika yang digunakan, yaitu elitisme, persilangan dan mutasi. Dalam AG yang diusulkan, ketiga operator dilakukan secara paralel. Jumlah individu yang dibentuk dari tiap operator ditentukan berdasarkan perkalian antara proporsi masing-masing yang telah ditetapkan dikalikan dengan ukuran populasi.

\section{Elitisme}

Elitisme merupakan operator yang melakukan pengambilan individu terbaik generasi sebelumnya. Elitisme diperlukan untuk menjamin bahwa individu terbaik tetap dipertahankan pada populasi dari satu generasi ke generasi berikutnya.

\section{Persilangan.}

Persilangan merupakan proses penggabungan dua string induk menjadi dua string anak yang berbeda dengan string induknya dengan cara mempertukarkan (mengambil informasi) bagian dari string induk. Berdasarkan nilai-nilai fitness, dua individu terbaik dari kedua induk dan kedua anak dipilih untuk menjadi individu pada populasi baru. Untuk setiap operasi persilangan, dua induk dipilih dengan metode roulette wheel. Misal $\boldsymbol{v}$ adalah suatu individu dalam populasi $\boldsymbol{P}$ dengan nilai fitness yang berasosiasi dinyatakan dengan $f(\boldsymbol{v})$. Probabilitas untuk individu $\boldsymbol{v} \in \boldsymbol{P}$ yang terpilih dinyatakan dengan:

$$
\operatorname{Prob}(v)=\frac{f(v)}{\sum_{v \in p} f(v)}
$$

\section{Mutasi.}

Mutasi berperan dalam melakukan perubahan pada suatu individu. Pemilihan induk yang dimutasi dilakukan secara acak dari individu-individu dalam populasi saat ini. Berdasarkan nilai-nilai fitness, individu terbaik dari induk dan anak dipilih untuk menjadi individu pada populasi.

\section{Hasil Percobaan}

AG yang dikembangkan diimplementsikan dalam suatu program komputer menggunakan bahasa pemrograman Visual Basic 6.0. Dalam percobaan, piranti lunak aplikasi dijalankan dengan komputer dengan spesifikasi sebagai berikut: prosesor Intel Pentium IV $1.8 \mathrm{GHz}$, memori DDRAM $256 \mathrm{MB}$, sistem operasi Microsoft Windows XP Professional Edition. Gambar 4 menunjukkan beberapa tampilan dari piranti lunak aplikasi yang dikembangkan.

AG yang diusulkan diuji coba menggunakan sembilan contoh hipotetik seperti yang terdapat dalam Suprayogi dan Priyandari (2007). Tiap contoh hipotetik memiliki 100 pelanggan. Lokasi-lokasi pelanggan dibangkitkan secara random antara koordinat $(0,0)$ dan $(600,600)$. Koordinat depot berada pada koordinat (300,300). Karakteristik jendela waktu untuk pelanggan dikelompokkan menjadi tiga, yaitu: sempit, lebar dan tercampur. Jendela waktu sempit dibangkitkan secara random antara 10 hingga 50. Jendela waktu lebar dibangkitkan antara 395 hingga 539. Jendela waktu campuran memiliki lebar antara 10 sampai 501. Karakteristik-karakteristik dari kesembilan contoh data hipotetik ditunjukkan pada Tabel 1. Gambar 5 menunjukkan lokasi pelanggan yang teracak, terkelompok dan tercampur.

Data-data yang lain adalah berikut ini:

- Waktu layanan baik depot maupun pelanggan adalah 10 menit.

- Kuantitas permintaan penjemputan dan kuantitas permintaan pengantaran adalah acak dengan rentang 1 hingga 10 unit.

- Kecepatan kendaraan adalah 40 km/ jam.

- Kapasitas kendaraan adalah 20 unit.

- Saat buka dan saat buka dari depot masingmasing adalah 0 dan 540.

- Penggunaan skala dalam data hipotetik adalah 1:60.

Dalam eksperimen, parameter-parameter algoritma genetika yang digunakan adalah berikut ini: jumlah generasi maksimum $=20$, ukuran populasi $=20$, tingkat proporsi elitisme $=50 \%$, tingkat proporsi persilangan $=30 \%$, dan tingkat proporsi mutasi $=20 \%$. Untuk perhitungan fitness, 
nilai bobot masing-masing adalah: $\boldsymbol{w}_{1}=100.000, \boldsymbol{w}_{2}$ $=0,4$ dan $\boldsymbol{w}_{3}=0,00005$. Hasil percobaan dengan melakukan 10 replikasi untuk setiap contoh hipotetik ditunjukkan pada Tabel 2.

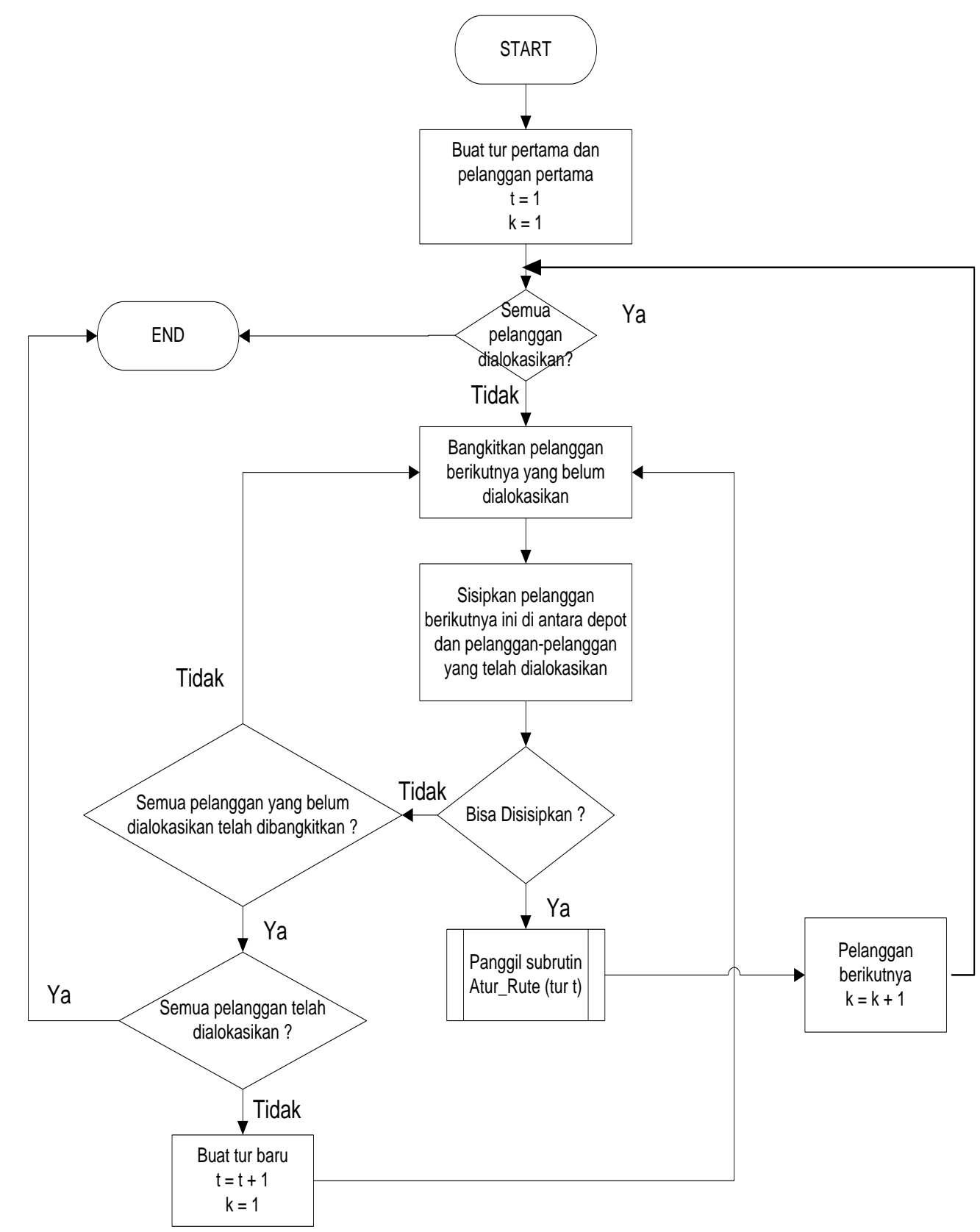

Gambar 2. Diagram Alir Utama dari Prosedur Pembentukan Individu dalam Populasi Awal 


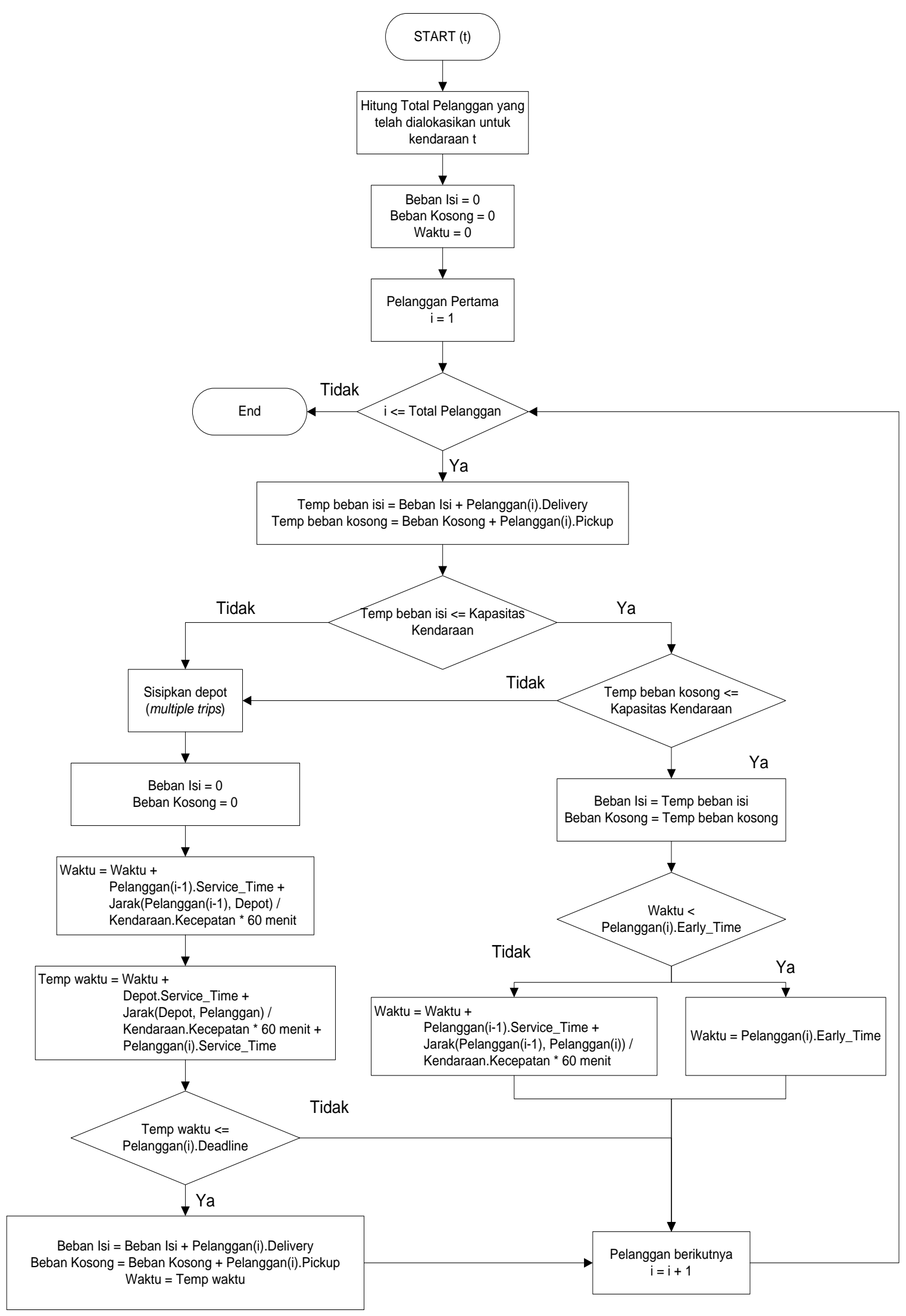

Gambar 3. Diagram Alir untuk Subrutin Pengaturan Rute pada Pembentukan Individu dalam Populasi Awal 


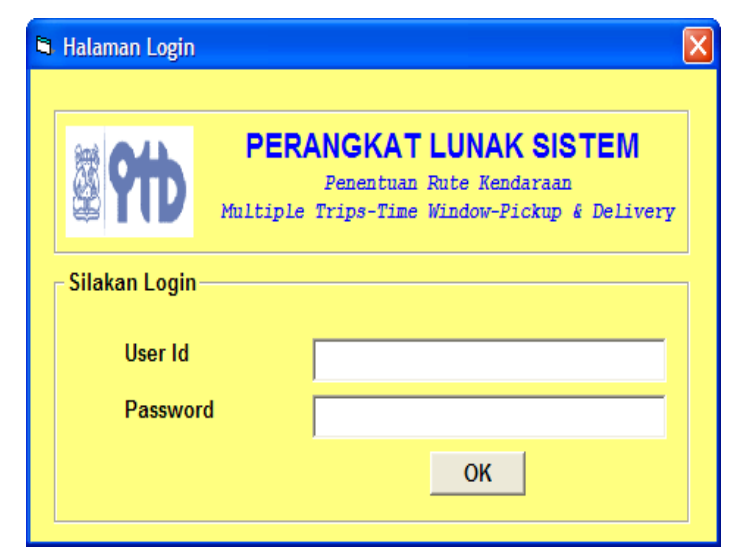

Tampilan login

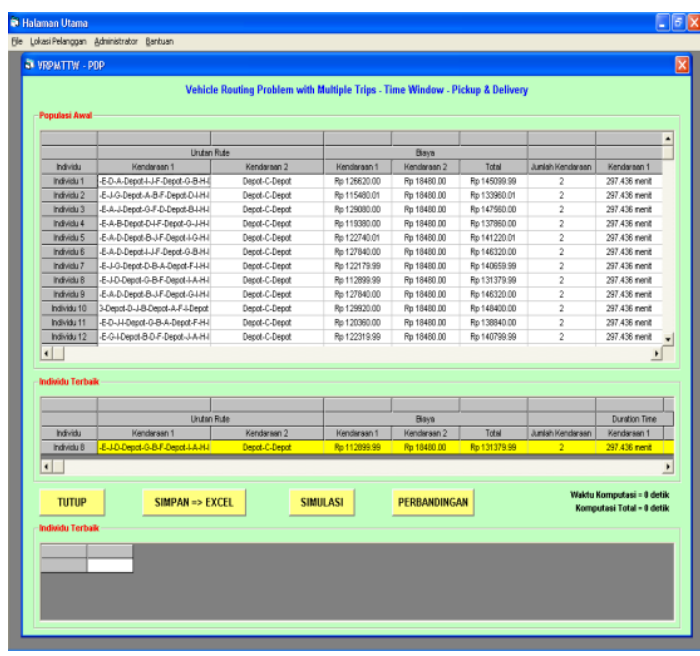

Tampilan proses

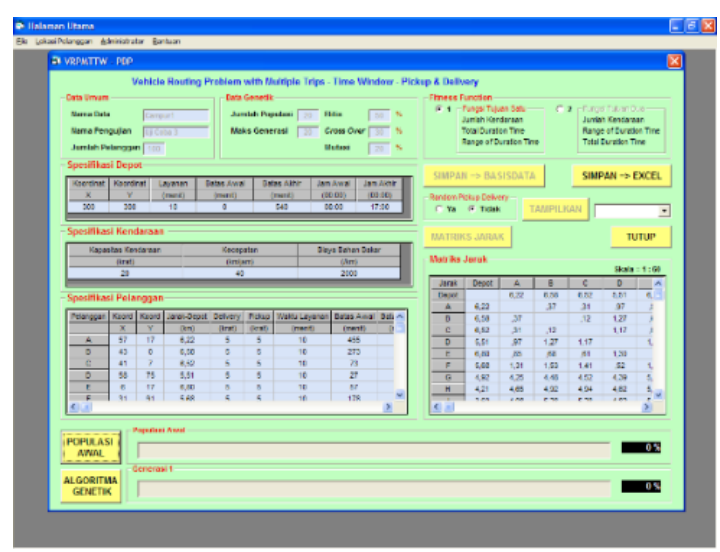

Tampilan data

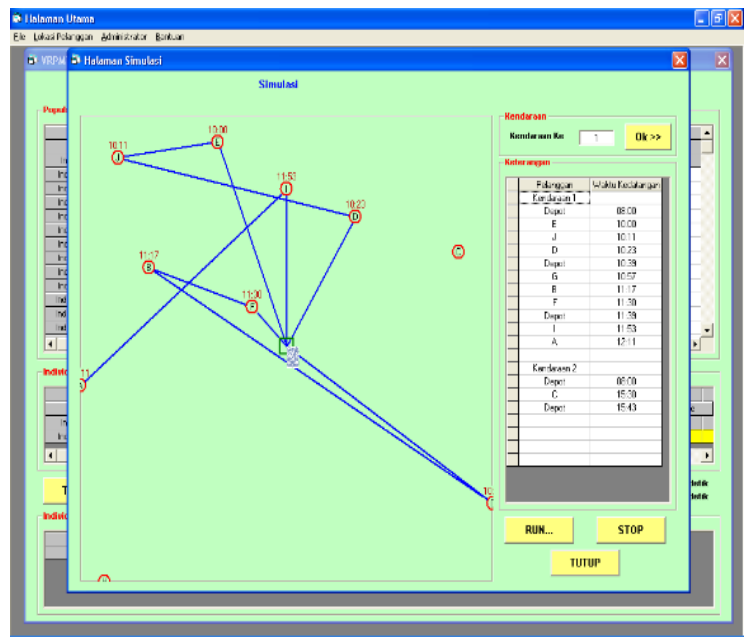

Tampilan peta tur

Gambar 4. Beberapa Tampilan dari Piranti Lunak Aplikasi

Tabel 1. Karakteristik-Karakteristik untuk Contoh-Contoh Hipotetik

\begin{tabular}{|c|c|c|c|c|}
\hline & & \multicolumn{3}{|c|}{ Jendela waktu } \\
\hline & & Sempit & Lebar & Tercampur \\
\hline \multirow{3}{*}{$\begin{array}{c}\text { Lokasi } \\
\text { pelanggan }\end{array}$} & Teracak & $\mathrm{R} 1$ & $\mathrm{R} 2$ & $\mathrm{R} 3$ \\
\hline & Terkelompok & $\mathrm{C} 1$ & $\mathrm{C} 2$ & $\mathrm{C} 3$ \\
\hline & Tercampur & M1 & M2 & M3 \\
\hline
\end{tabular}




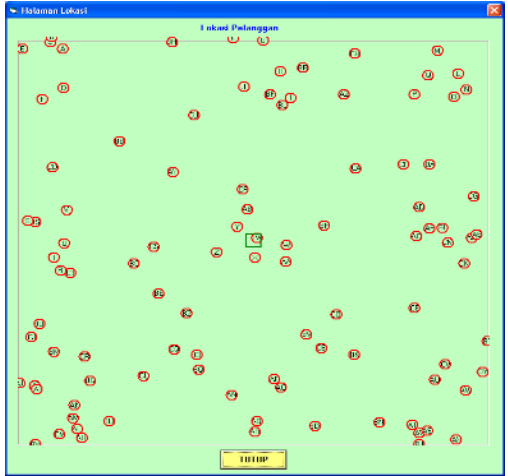

Lokasi pelanggan teracak

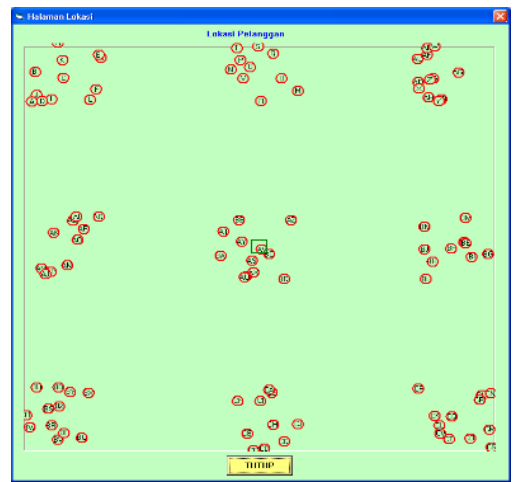

Lokasi pelanggan terkelompok

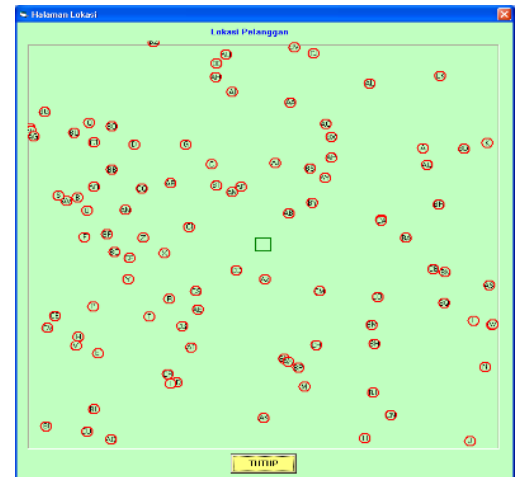

Lokasi pelanggan tercampur

Gambar 5. Lokasi Pelanggan

Tabel 2. Hasil-Hasil Percobaan

\begin{tabular}{|c|c|c|c|c|c|c|}
\hline \multicolumn{2}{|c|}{ Contoh } & $\begin{array}{c}\text { Jumlah } \\
\text { Kendaraan }\end{array}$ & $\begin{array}{c}\text { Total waktu } \\
\text { durasi tur }\end{array}$ & $\begin{array}{l}\text { Rentang waktu } \\
\text { durasi tur }\end{array}$ & Nilai fitness & $\begin{array}{l}\text { Waktu } \\
\text { komputasi }\end{array}$ \\
\hline \multirow{2}{*}{$\mathrm{R} 1$} & Terbaik & 8,00 & 3515,09 & 111,59 & 801406,1 & 122,0 \\
\hline & Rata-rata & 8,00 & 3552,94 & 131,93 & 801422,1 & 146,2 \\
\hline \multirow{2}{*}{ R2 } & Terbaik & 4,00 & 1704,54 & 312,18 & 400681,8 & 59,0 \\
\hline & Rata-rata & 4,00 & 1704,54 & 312,18 & 400681.8 & 60,0 \\
\hline \multirow{2}{*}{ R3 } & Terbaik & 6,00 & 2905,94 & 112,11 & 600195,3 & 84,0 \\
\hline & Rata-rata & 6,00 & 2944,76 & 136,05 & 601077,9 & 84,7 \\
\hline \multirow{2}{*}{$\mathrm{C} 1$} & Terbaik & 7,00 & 3188,66 & 59,05 & 701275,7 & 115,0 \\
\hline & Rata-rata & 7,00 & 3318,59 & 155,00 & 701327,5 & 247,9 \\
\hline \multirow{2}{*}{$\mathrm{C} 2$} & Terbaik & 4,00 & 1713,20 & 157,70 & 400685,3 & 61,0 \\
\hline & Rata-rata & 4,00 & 1719,68 & 291,34 & 400687,9 & 62,3 \\
\hline \multirow{2}{*}{ C3 } & Terbaik & 5,00 & 2575,27 & 8,77 & 501030,1 & 78,0 \\
\hline & Rata-rata & 5.30 & 2706,46 & 82,55 & 531082,6 & 124,5 \\
\hline \multirow{2}{*}{ M1 } & Terbaik & 7,00 & 2718,07 & 115,38 & 701148,5 & 168,0 \\
\hline & Rata-rata & 7.69 & 3006,35 & 435,68 & 771302,7 & 195,9 \\
\hline \multirow{2}{*}{ M2 } & Terbaik & 4,00 & 1729,48 & 173.50 & 400691,8 & 60,0 \\
\hline & Rata-rata & 4,00 & 1732,91 & 223,22 & 400693,2 & 61,5 \\
\hline \multirow{2}{*}{ M3 } & Terbaik & 5,00 & 2563,62 & 13,69 & 501025,4 & 76,0 \\
\hline & Rata-rata & 5,00 & 2593,90 & 24,91 & 501037,5 & 126,2 \\
\hline
\end{tabular}




\section{Kesimpulan dan Saran Tindak Lanjut Penelitian}

Makalah ini telah membahas salah satu perluasan dari masalah rute kendaraan (MRK) dasar dengan karakteristik-karakteristik yang mencakup: (1) trip majemuk (TM), (2) jendela waktu (JW) dan (3) pengantaran-penjemputan simultan (AJS). MRK yang dibahas dalam makalah ini (disingkat dengan MRKTM-JW-AJS) memiliki ukuran kinerja majemuk, yaitu meminimumkan jumlah kendaraan yang digunakan, meminimumkan total waktu durasi tur dan meminimumkan rentang waktu durasi tur. Penanganan ukuran kinerja majemuk dilakukan dengan metode jumlah terbobot.

Metode pemecahan yang berbasis algoritma genetika (AG)) telah dikembangkan sebagai metode pemecahan. Algoritma penyisipan sekuensial diterapkan untuk menghasillkan individu-individu dalam populasi awal. Metode pemecahan yang dikembangkan telah diimplementasikan dalam suatu piranti lunak.

Penelitian lanjutan dapat dilakukan dengan mengembangkan lebih lanjut dari teknik pemecahan yang diusulkan, misalnya dengan menerapkan teknik hibrid. Pengembangan lanjutan ini diharapkan dapat meningkatkan kinerja dari metode pemecahan.

\section{Daftar Pustaka}

Avci, M., Topaloglu, S. (2015). An adaptive local search algorithm for vehicle routing problem with simultaneous and mixed pickups and deliveries. Computers \& Industrial Engineering $83,15-29$.

Azi, N., Gendreau, M., Potvin, J. -Y. (2010). An exact algorithm for a vehicle routing problem with time windows and multiple use of vehicles. European Journal of Operational Research 202, 756-763.

Battarra, M., Monaci, M., Vigo, D. (2009). An adaptive guidance approach for the heuristic solution of a minimum multiple trip vehicle routing problem. Computers \& Operations Research 36, 3041--3050.

Bodin, L., Golden, L. (1981). Classification in vehicle routing and scheduling, Networks 11, 97-108.

Brandão, J., Mercer, A. (1997). A tabu search algorithm for the multi-trip vehicle routing and scheduling problem, European Journal of Operational Research 100, 180-191.

Cattaruzza, D., Asbi, N., Feillet, D. (2014). The multi trip vehicle routing problem with time windows and release dates. Working Paper EMSE CMPSFL 2014/1, Ecole des Mines de Saint-Etienne, Department of Manufacturing Sciences and Logistics.

Dantzig, G., Ramser, J. (1959). The truck dispatching problem, Management Science 6, 80-91.

Fan, J. (2011). The vehicle routing problem with simultaneous pickup and delivery based on customer satisfaction. Procedia Engineering, Volume 15, 5284-5289.
Hernandez, F., Feillet, D., Giroudeau, R., Naud, O. (2014). A new exact algorithm to solve the multi-trip vehicle routing problem with time windows and limited duration. $4 Q R-Q J$ Oper Res 12, 235-259.

Hernandez, F., Feillet, D., Giroudeau, R., Naud, O. (2016). Branch-and-price algorithms for the solution of the multi-trip vehicle . European Journal of Operational Research 249, 551-559.

Lenstra, J.K., Rinnooy-Kan, A H. (1981) Complexity of the vehicle routing and scheduling problems, Networks 11, 221-227.

Liu, R., Xie, X., Augusto, V., Rodriguez, C. (2013). Heuristic algorithms for a vehicle routing problem with simultaneous delivery and pickup and time windows in home health care. European Journal of Operational Research 230 , 475-486.

Marcedo, R., Alves, C., de Carvalho, V., Clautiaux, F., Hanafi, S. (2011). Solving the vehicle routing problem with time windows and multiple routes exactly using a pseudo-polynomial model. Europeam Journal of Operational Research 214, 536-545.

Min, H. (1989). The multiple vehicle routing problem with simultaneous delivery and pick-up point, Transportation Research 23 A (5), 377-386.

Mingyong, L., Erbao, C. (2010). An improved differentia levolution algorithm for vehicle routing problem with simultaneous pickup sand deliveries and time windows. Engineering Applications of Artificial Intelligence 23, 188195.

Nguyen, P. K., Crainic, T. G., Toulouse, M. (2013). A tabu search for time-dependent multi-zone multitrip vehicle routing problem with time windows. European Journal of Operational Research 231, 43-56.

Ong, J. O., \& Suprayogi. (2011). Vehicle routing problem with backhaul, multiple trips and time windows. Jurnal Teknik Industri 13 (1), 1-10.

Savelsbergh, M. (1992). The vehicle routing problem with time windows: Minimizing route duration, ORSA Journal of Computing 4 (2), 146-154.

Solomon, M.M. (1987). Algorithms for the vehicle routing and scheduling problem with time window constraints, Operations Research 35, 254-265.

Suprayogi. (2003). Sequential insertion algorithm for solving the vehicle routing problem with multiple trips and time windows. Jurnal Teknik dan Manajemen Industri 23 (3), 30-46.

Suprayogi; Imawati, D. (2005). Sequential insertion algorithm with forward and backward passes for solving the vehicle routing problem with multiple trips and time windows (in Indonesian). Jurnal Teknik dan Manajemen Industri 25 (1), 41-54.

Suprayogi; Priyandari, Y. (2007) Teknik penyisipan sekuensial untuk penentuan rute kendaraan 
dengan karakteristik banyak trip, jendela waktu dan pengantaran-pengambilan simultan, Jurnal Teknik dan Manajemen Industri, 27 (3), 103-124.

Suprayogi; Priyandari, Y. (2009). Vehicle routing problem with multiple trips, time windows, and simultaneous delivery and pickup services, Proceedings of Asia Pacific Conference on Industrial Engineering and Management, Kitakyushu, Japan, 1543-1552.

Suprayogi; Hardianto, A., Yamato, H. (2005). Local search and genetic algorithm techniques for solving vehicle routing problem with multiple trips and time windows. Proceedings of International Conference on Operations and Supply Chain Management, (pp. J17-J24). Bali, Indonesia.

Suprayogi; Hidayat, Y. A., Imawati, D. (2011). Simulated annealing for solving the vehicle routing and scheduling problem with multiple trips and time windows (in Indonesian). Proceedings of 6th National Industrial Engineering Conference 2011, (pp. 242-249). Surabaya, Indonesia.

Suprayogi; Imawati, D., Hardianto, A. (2007). Local search technique for solving the vehicle routing problem with multiple trips and time windows (in Indonesian). Jurnal Teknik dan Manajemen Industri 27 (2), 57-75.
Suprayogi; Imawati, D., Hardianto, A. (2007). Teknik local search untuk pemecahan vehicle routing problem with multiple trips and time windows, Jurnal Teknik dan Manajemen Industri 27 (2), 57-75.

Taillard, E. D., Laporte, G., Gendreau, M. (1996). Vehicle routeing with multiple use of vehicles, Journal of the Operational Research Society 47 (8), 1065-1070.

Wang, C., Mu, D., Zhao, F., Sutherland, J. W. (2015). A parallel simulated annealing method for the vehicle routing problem with simultaneous pickup-delivery and time windows. Computers \& Industrial Engineering 83, 111-122.

Wang, H., Chen, Y. Y. (2013). A coevolutionary algorithm for the flexible delivery and pickup problem with time windows. International Journal of Production Economics 141, 4-13.

Wang, H. -F., Chen, Y. Y. (2012). A genetic algorithm for the simultaneous delivery and pickup problems with time windows. Computers \& Industrial Engineering 62, 84-95. 